\title{
Analisis Korelasi Umur, Paritas dan Jarak Kehamilan dengan Berat Badan Lahir
}

\author{
Risa Devita ${ }^{1}$, Neni Riyanti ${ }^{2}$ \\ STIKES Aisyiyah Palembang ${ }^{1,2}$
}

Informasi Artikel :

Diterima :24 November 2021

Direvisi : 03 Desember 2021

Disetujui : 20 Desember 2021

Diterbitkan : 30 Desember 2021

*Korespondensi Penulis : Risadevita84@gmail.com

\section{A B S T R A K}

Berat badan lahir merupakan indikator penting terkait kerentanan terhadap risiko penyakit dan kelangsungan hidup anak. Berat badan lahir, ditimbang dalam waktu satu jam sesudah lahir. Risiko kehamilan pada umur di atas 35 tahun ke atas menyebabkan risiko meninggal atau cacat pada bayi dan ibu hamil dan mempengaruhi berat badan lahir pada bayi, paritas yang terlalu banyak dapat menyebabkan terjadinya gangguan dalam kehamilan, menghambat proses persalinan, menyebabkan perdarahan, dan ibu memiliki jarak kehamilan yang terlalu dekat/jauh dapat menyebabkan keguguran anemia,dan prematur. Penelitian untuk mengetahui hubungan umur, paritas, dan jarak kehamilan dengan berat badan lahir. Metode penelitian secara kuantitatif yang bersifat deskriptif analitik dengan pendekatan retrospektif. Sampel diambil secara simple random sampling berjumlah 121 responden dengan instrument lembar rekam medik ibu bersalin di Praktik Mandiri Bidan Mitra Mulia Banyuasin Tahun 2017-2109. Analisis data menggunakan uji korelasi pearsonproduct moment. Penelitian ini dilakukan pada bulan November 2020 - Februari 2021. Hasil penelitian didapatkan variabel umur diperoleh nilai positif $(\mathrm{r}=$ $0,070)$, korelasi umur dengan berat badan lahir dengan signifikasi $(p=0,447)$ sehingga tidak terdapat korelasi yang bermakna antara umur dengan berat badan lahir. Variabel paritas diperoleh nilai positif $(r=0,06)$, korelasi paritas dengan berat badan lahir dengan signifikasi $(\mathrm{p}=0,504)$ sehingga tidak terdapat nilai korelasi yang bermakna antara paritas dengan berat badan lahir. Variabel jarak kehamilan diperoleh nilai negatif $(\mathrm{r}=-0,503)$, korelasi jarak kehamilan dengan berat badan lahirdengan signifikasi $(p=0,062)$ sehingga tidak terdapat korelasi yang bermakna antara jarak kehamilan dengan berat badan lahir.

\section{Kata Kunci : Berat Badan Lahir, Umur, Paritas, Jarak Kehamilan}

\begin{abstract}
Birth weight is an important indicator of susceptibility to disease risk and child survival. Birth weight is weighed within an hour of birth. The risk of pregnancy at the age of 35 years and above causes the risk of death or disability in infants and pregnant women and affects the birth weight in the baby, too much parity can cause disorders in pregnancy, inhibit the delivery process, cause bleeding, and mothers have a pregnancy distance that is too close I far can cause anemia miscarriage, and premature. Research to find out the correlation of age, parity, and distance of pregnancy with birth weight. The research method is quantitative descriptive analytic with a retrospective approach. The sample was taken simply random sampling amounting to 121 respondents with a medical record sheet instrument of maternity mothers at the independent midwife's practice Mitra Mulia Banyuasin in 2017-
\end{abstract}


2109. The results of the study obtained a positive age variable $(r=$ $0.070)$, a correlation of age with birth weight with signification ( $p$ $=0.447)$ so there is no meaningful correlation between age and birth weight. The variable of parity obtained a positive value $(r=$ 0.06), the correlation of parity with birth weight with signification $(p=0.504)$ so that there is no meaningful correlation value between parity and birth weight. Variable pregnancy distance obtained negative value $(r=-0.503)$, correlation of pregnancy distance with birth weight with signification $(p=0.062)$ so there is no meaningful correlation between pregnancy distance and birth weight.

\section{Keywords : Birth Weight, Age, Parity, Pregnancy Distance}

\section{PENDAHULUAN}

Bayi memerlukan pemantauan ketat untuk menentukan masa transisi kehidupan diluar uterus sehingga dapat dengan berlangsung baik.Bayi baru lahir membutuhkan asuhan yang dapat meningkatkan kesempatan untuknya menjalani masa transisi dengan baik (Muslihatun 2010).Berat badan lahir merupakan indikator penting terkait kerentanan terhadap risiko penyakit dan kelangsungan hidup anak. Anak -anak yang lahir dengan berat badan kurang dari 2,5 kilogram, yaitu berat badan lahir rendah, memiliki resiko lebih tinggi terjadi kematian pada umur dini (SDKI, 2017).

Berat badan lahir merupakan berat badan neonatus pada saat kelahiran, ditimbang dalam waktu satu jam sesudah lahir (Muslihatun, 2010).Tidak semua bayi diketahui berat badan lahirnya, baik dari cacatan tertulis maupun ingatan ibu. Hasil Survei Demografi Kesehatan Indonesia (SDKI) tahun 2017, kelahiran bayi di Indonesia yang memiliki laporan berat lahir sebanyak 16.023 (94,1\%). Dari data tersebut didapatkan 92,9\% kelahiran dengan berat badan $2,5 \mathrm{~kg}$ atau lebih dan 7,1\% kelahiran dengan berat badan kurang dari $2,5 \mathrm{~kg}$. Provinsi dengan persentase distribusi kelahiran berat badan 2,5 $\mathrm{kg}$ atau lebih tertinggi adalah provinsi Bangka Belitung sebesar 96\%, sedangkan provinsi dengan persentase terendah adalah provinsi Nusa Tenggara Timur sebesar 86,6\% (SDKI, 2017)

Data SDKI tahun 2017, di provinsi Sumatera Selatan tercatat $95,5 \%$ kelahiran memiliki laporan berat lahir dengan persentase kelahiran berat badan $2,5 \mathrm{~kg}$ atau lebih sebesar $94,2 \%$ dan berat badan kurang dari 2,5 kg sebesar 50,8\%. Di kabupaten Banyuasin terdata 16.274 kelahiran hidup dimana $88,5 \%$ bayi baru lahir ditimbang dan $00,8 \%$ dengan status berat bayi lahir rendah (Dinkes Banyuasin, 2018).

Beberapa hasil penelitian menunjukkan secara statistik ada hubungan yang signifikan antara umur, paritas, jarak kehamilan dengan berat bayi lahir (Endriana dkk, 2012). Kajian literatur dan hasil penelitian terdahulu faktorfaktor predisposisi terhadap berat bayi lahir, antara lain umur ibu hamil, paritas, jarak kehamilan, Hemoglobin (Hb), status gizi, pemeriksaan saat hamil, pekerjaan.

Hasil studi pendahuluan di Praktik Mandiri Bidan (PMB) Mitra Mulia Banyuasin tahun 2017-2019 jumlah ibu bersalin sebanyak $173 \mathrm{ibu}$ bersalin rata-rata berat badan lahir dalam kategori normal. Dari latar belakang diatas peneliti tertarik untuk meneliti tentang analisis korelasi umur, paritas, dan jarak kehamilan dengan berat badan lahir di PMB Mitra Mulia Banyuasin. 


\section{METODE PENELITIAN}

Jenis penelitian ini merupakan penelitian kuantitatif yang bersifat deskriptif analitik dengan pendekatan atau rancangan "retrospective".Dimana variabel independen (umur, paritas dan jarak kehamilan) variabel dependen (berat badan lahir) dikumpulkan dalam waktu bersamaan.

Sampel pada penelitian ini adalah sebagian ibu bersalin di PMB Mitra Mulia Banyuasin dari Tahun 2017-2029 yang berjumlah 121 responden.Pengambilan sampel pada penelitian ini dilakukan dengan cara random atau acak dengan metode simple random sampling.

Analisa yang digunakan adalah uji parametrik dengan uji kolerasi pearson product momentyaitu untuk mengetahui kekuatan dan arah hubungan antara variabel numerik dan variabel numerik. Data akan diolah dengan bantuan computerized dengan tingkat kepercayaan yang digunakan adalah 95\% dengan $\alpha$ (tingkat kemaknaan) sebesar 0,05 . Dimana jika nilai $\rho$ value $\leq \alpha(0,05)$ berarti terdapat korelasi yang bermakna antara dua variabel (berat badan lahir dengan umur, paritas dan jarak kehamilan), jika nilai $\rho$ value $>\alpha(0,05)$ berarti tidak terdapat kolerasi yang bermakna antara dua variabel (berat badan lahir dengan umur, paritas dan jarak kehamilan). Serta jika nilai $r$ (kekuatan korelasi) : 0,00-0,199 memiliki interpretasi sangat lemah; 0,20-0,399 memiliki interprestasi lemah; 0,40-0,599 memiliki interprestasi sedang; 0,60-0,799 memiliki interpretasi kuat; 0,80-1,000 memiliki interpretasi sangat kuat.

\begin{tabular}{lll}
\hline \multicolumn{1}{c}{ Parameter } & \multicolumn{1}{c}{ Nilai } & \multicolumn{1}{c}{ Interpretasi } \\
\hline Kekuatan & $0,00-0,199$ & Sangat Lemah \\
Korelasi ( r ) & $0,20-0,399$ & Lemah \\
& $0,40-0,599$ & Sedang \\
& $0,60-0,79$ & Kuat \\
& $0,80-1,000$ & Sangat Kuat \\
\hline & & Terdapat \\
Nilai p & $\mathrm{P}<0,05$ & korelasi yang \\
& & bermakna antara \\
\hline
\end{tabular}

dua variabel yang diuji.

Tidak terdapat $\mathrm{P}>0,05 \quad$ korelasi yang bermakna antara dua variabel yang diuji.

Searah, semakin
Arah + (Positif)

Korelasi

- (Negatif) besar nilai satu variabel semakin besar pula nilai variabel lainnya.

Berlawanan arah. Semakin besar nilai satu variabel, semakin kecil nilai variabel lainnya.

\section{HASIL PENELITIAN}

1. Analisa Univariat

Tabel 1. Distribusi Frekuensi Berat Badan Lahir

\begin{tabular}{cccc}
\hline No & $\begin{array}{c}\text { Berat Bayi Lahir } \\
\text { (Dalam Gram) }\end{array}$ & $\mathbf{f}$ & $\mathbf{\%}$ \\
\hline 1 & 2000 & 1 & 0,8 \\
\hline 2 & 2100 & 1 & 0,8 \\
\hline 3 & 2200 & 1 & 0,8 \\
\hline 4 & 2300 & 1 & 0,8 \\
\hline 5 & 2500 & 10 & 8,3 \\
\hline 6 & 2600 & 13 & 10,7 \\
\hline 7 & 2700 & 8 & 6,6 \\
\hline 8 & 2800 & 13 & 10,7 \\
\hline 9 & 2900 & 16 & 13,2 \\
\hline 10 & 3000 & 15 & 12,4 \\
\hline 11 & 3100 & 7 & 5,8 \\
\hline 12 & 3200 & 5 & 4,1 \\
\hline 13 & 3300 & 4 & 3,3 \\
\hline 14 & 3400 & 8 & 6,6 \\
\hline 15 & 3500 & 8 & 6,6 \\
\hline 16 & 3600 & 2 & 1,7 \\
\hline 17 & 3700 & 1 & 0,8 \\
\hline 18 & 3800 & 3 & 2,5 \\
\hline
\end{tabular}


Jurnal Kebidanan : Jurnal Medical Science Ilmu Kesehatan Akademi Kebidanan Budi Mulia Palembang Volume.11 No.2, Desember 2021

Available online https://journal.budimulia.ac.id/

\begin{tabular}{cccc}
\hline \hline 19 & 3900 & 2 & 1,7 \\
\hline 20 & 4000 & 1 & 0,8 \\
\hline 21 & 4100 & 1 & 0,8 \\
\hline & Total & $\mathbf{1 2 1}$ & $\mathbf{1 0 0}$ \\
\hline
\end{tabular}

Berdasarkan tabel 1, dari 121 responden yang mempunyai berat bayi lahir $<2500$ gram ada 4 responden $(3,2 \%)$. Berat bayi lahir 2500 - 4000 gram ada 116 responden (96\%) dan berat bayi lahir $>4000$ gram ada 1 responden $(0,8 \%)$.

Tabel 2. Distribusi Frekuensi Umur Ibu

\begin{tabular}{|c|c|c|c|}
\hline No & $\begin{array}{c}\text { Umur Ibu } \\
\text { (Dalam Tahun) }\end{array}$ & f & $\%$ \\
\hline 1 & 19 & 1 & 0,8 \\
\hline 2 & 20 & 4 & 3,3 \\
\hline 3 & 21 & 2 & 1,7 \\
\hline 4 & 22 & 4 & 3,3 \\
\hline 5 & 23 & 4 & 3,3 \\
\hline 6 & 24 & 4 & 3,3 \\
\hline 7 & 25 & 5 & 4,1 \\
\hline 8 & 26 & 7 & 5,8 \\
\hline 9 & 27 & 8 & 6,6 \\
\hline 10 & 28 & 8 & 6,6 \\
\hline 11 & 29 & 12 & 9,9 \\
\hline 12 & 30 & 14 & 11,6 \\
\hline 13 & 31 & 8 & 6,6 \\
\hline 14 & 32 & 9 & 7,4 \\
\hline 15 & 33 & 4 & 3,3 \\
\hline 16 & 34 & 10 & 8,3 \\
\hline 17 & 35 & 4 & 3,3 \\
\hline 18 & 36 & 6 & 5,0 \\
\hline 19 & 37 & 1 & 0,8 \\
\hline 20 & 40 & 3 & 2,5 \\
\hline 21 & 41 & 1 & 0,8 \\
\hline 22 & 43 & 2 & 1,7 \\
\hline \multicolumn{2}{|r|}{ Total } & 121 & 100 \\
\hline
\end{tabular}

Berdasarkan tabel 2, dari 121 responden yang mempunyai umur $<20$ tahun ada 1 responden $(0,8 \%)$, umur $20-35$ tahun ada 107 responden $(88,4 \%)$ dan umur $>35$ tahun ada 13 responden $(10,8 \%)$.

\begin{tabular}{cccc}
\multicolumn{4}{l}{ Tabel 3. Distribusi Frekuensi Paritas } \\
\hline No & Paritas & f & \% \\
\hline 1 & 0 & 2 & 1,7 \\
\hline 2 & 1 & 54 & 44,6 \\
\hline 3 & 2 & 39 & 32,2 \\
\hline 4 & 3 & 18 & 14,9 \\
\hline 5 & 4 & 8 & 6,6 \\
\hline \multicolumn{7}{c}{ Total } & $\mathbf{1 2 1}$ & $\mathbf{1 0 0}$ \\
\hline
\end{tabular}

Berdasarkan tabel 3, didapatkan bahwa dari 121 responden yang mempunyai paritas $0-1$ (primipara) ada 56 responden $(46,3 \%)$, paritas 2-3 (multipara) ada 57 responden $(47,1 \%)$ dan paritas $>3$ (grande multipara) ada 8 responden $(6,6 \%)$.

Tabel 4. Distribusi Frekuensi Jarak Kehamilan

\begin{tabular}{cccc}
\hline No & $\begin{array}{c}\text { Jarak Kehamilan } \\
\text { (Dalam Tahun) }\end{array}$ & $\mathbf{f}$ & $\mathbf{\%}$ \\
\hline 1 & 1 & 5 & 4,1 \\
\hline 2 & 1 & 1 & 0,8 \\
\hline 3 & 2 & 1 & 0,8 \\
\hline 4 & 2 & 13 & 10,7 \\
\hline 5 & 2 & 1 & 0,8 \\
\hline 6 & 3 & 1 & 0,8 \\
\hline 7 & 3 & 1 & 0,8 \\
\hline 8 & 3 & 19 & 15,7 \\
\hline 9 & 3 & 1 & 0,8 \\
\hline 10 & 4 & 21 & 17,4 \\
\hline 11 & 5 & 1 & 0,8 \\
\hline 12 & 5 & 24 & 19,8 \\
\hline 13 & 6 & 1 & 0,8 \\
\hline 14 & 6 & 7 & 5,8 \\
\hline 15 & 7 & 7 & 5,8 \\
\hline 16 & 8 & 5 & 4,1 \\
\hline 17 & 9 & 3 & 2,5 \\
\hline 18 & 10 & 3 & 2,5 \\
\hline 19 & 12 & 4 & 3,3 \\
\hline 20 & 14 & 1 & 0,8 \\
\hline 21 & 16 & 1 & 0,8 \\
\hline & Total & $\mathbf{1 2 1}$ & $\mathbf{1 0 0}$ \\
\hline & & & \\
\hline
\end{tabular}

Berdasarkan tabel 4, didapatkan bahwa dari 121 responden yang mempunyai jarak 
kehamilan $<2$ tahun ada 6 responden $(4,9 \%)$, jarak kehamilan $>2-6$ tahun ada 91 responden $(75,3 \%)$ dan jarak kehamilan $>6$ tahun ada 24 responden $(19,8 \%)$.

\section{Analisa Bivariat}

a. Analisa Korelasi Berat Badan Lahir Dengan Umur Ibu di Praktik Mandiri Bidan Mitra Mulia

Tabel 5. Analisa Korelasi Berat Badan Lahir Dengan Umur Ibu

\begin{tabular}{ccc}
\hline & Koefisien & Umur Ibu \\
\hline Berat Badan & $\mathrm{r}$ & 0,070 \\
Lahir & $\mathrm{p}$ & 0,447 \\
& $\mathrm{n}$ & 121 \\
\hline
\end{tabular}

Uji korelasi pearson dari tabel 5, di peroleh nilai $r$ (kekuatan korelasi) 0,070 menunjukkan kekuatan korelasi sangat lemah antara umur dengan berat badan lahir tetapi bernilai positif artinya searah, semakin besar nilai satu variabel semakin besar pula nilai variabel lainnya.Secara statistik diperoleh nilai $p$ value $(0,447)>\alpha(0,05)$ menunjukkan tidak terdapat korelasi yang bermakna antara berat badan lahir dengan umur.

b. Analisa Korelasi Berat Badan Lahir Dengan Paritas Ibu di Praktik Mandiri Bidan Mitra Mulia Banyuasin

Tabel 6. Analisa Korelasi Berat Badan Lahir Dengan Paritas

\begin{tabular}{ccc}
\hline & Koefisien & Paritas \\
\hline Berat & $\mathrm{R}$ & 0,071 \\
Badan & $\mathrm{p}$ & 0,437 \\
Lahir & $\mathrm{n}$ & 121 \\
\hline
\end{tabular}

Uji korelasi pearson dari tabel 6 , di peroleh nilai $\mathrm{r}$ (kekuatan korelasi) 0,061 menunjukkan kekuatan korelasi sangat lemah antara umur dengan Berat Badan Lahir tetapi bernilai positif artinya searah, semakin besar nilai satu variabel semakin besar pula nilai variabel lainya. Secara statistik diperoleh nilai $p$ value $(0,504)>\alpha(0,05)$ menunjukkan tidak terdapat korelasi yang bermakna antara Berat Badan Lahir dengan paritas.

c. Analisa Korelasi Berat Badan Lahir Dengan Jarak Kehamilan di Praktik Mandiri Bidan Mitra Mulia

Tabel 7. Analisa Korelasi Berat Badan Lahir Dengan Jarak Kehamilan

\begin{tabular}{|r|c|c|}
\hline & $\begin{array}{c}\text { Koefisi } \\
\text { en }\end{array}$ & $\begin{array}{c}\text { Jara } \\
\mathbf{k} \\
\text { Kehamila } \\
\mathbf{n}\end{array}$ \\
\hline $\begin{array}{c}\text { Ber } \\
\text { at Badan }\end{array}$ & $\mathrm{R}$ & - \\
Lahir & $\mathrm{p}$ & 0,062 \\
& $\mathrm{n}$ & 0,50 \\
& & 3 \\
& & 121 \\
\hline
\end{tabular}

Uji korelasi pearson dari tabel 7, di peroleh nilai $\mathrm{r}$ (kekuatan korelasi) 0,503 menunjukkan kekuatan korelasi sangat lemah tetapi bernilai negatif artinya berlawanan arah, dimana semakin besar nilai satu variabel, semakin kecil nilai variabel lainnya. Secara statistik diperoleh nilai $p$ value $(-0,062)>\alpha$ $(0,05)$ menunjukkan tidak terdapat korelasi yang bermakna antara berat badan lahir dengan jarak kehamilan.

\section{PEMBAHASAN}

1. Hubungan antara umur ibu dengan berat badan lahir.

Uji korelasi pearson di peroleh nilai $p$ value $(0,447)>\alpha(0,05)$ menunjukkan tidak terdapat korelasi yang bermakna antara Berat Badan Lahir dengan umur. Nilai r (kekuatan korelasi) sebesar 0,070 menunjukkan kekuatan korelasi sangat lemah tetapi bernilai positif artinya searah, dimana semakin besar nilai satu variabel semakin besar pula nilai variabel lainnya (Ho) ditolak. 
Hasil penelitian ini berbeda dengan hasil penelitian Endriana, dkk (2012), yang menunjukkan ada hubungan antara umur ibu dengan berat badan lahir.Begitu juga hasil penelitian Wahyuningrum,dkk (2015), menyatakan ada hubungan antara paritas dengan berat badan lahir.

Umur kehamilan dapat mempengaruhi berat badan lahir, umur kehamilan menentukan berat badan semakin tua kehamilan, berat janin akan bertambah. Pada umur kehamilan 28 minggu berat janin \pm 1000 gram, sedangkan pada umur kehamilan 37-42 minggu berat janin diperkirakan antara 2500 gram sampai 4000 gram. Seorang wanita yang hamil dengan umur kurang dari 20 tahun dapat mempengaruhi berat badan lahir rendah atau pun prematur, hal ini disebabkan perkembangan organorgan reproduksi dan fungsi fisiologi belum optimal.Selain itu emosi dan kejiwaannya belum matang, sehingga pada saat kehamilan tersebut belum dapat menanggapi kehamilannya secara sempurna dan terjadi komplikasi.Sedangkan ibu yang berumur 20-35 tahun dapat mengurangi kejadian berat badan lahir rendah ataupun prematur (Sarwono,2014).Sehingga dalam penelitian ini dapat disimpulkan bahwa usia ibu mayoritas 25-35 tahun bearti usia ibu ini dalam ketegori reproduksi sehat.

\section{Hubungan antara paritas ibu dengan berat badan lahir.}

Uji korelasi pearson di peroleh nilai $\rho$ value $(0,071)>\alpha(0,05)$ menunjukkan tidak terdapat korelasi yang bermakna antara Berat Badan Lahir dengan paritas. Nilai r (kekuatan korelasi) sebesar 0,437 menunjukkan arah korelasi positif artinya searah, dimana semakin besar nilai satu variabel semakin besar pula nilai variabel lainyadengan kekuatan korelasi yang sangat lemah (Ho) di tolak.

Hal ini sejalan dengan hasil penelitian Wigunantiningsih, dkk (2017) menyatakan tidak ada hubungan antara jarak kehamilan dan berat badan lahir.Sedangkan hasil penelitian Purnaningsih, dkk (2015), tidak sejalan dimana menunjukkan ada hubungan antara jarak kehamilan dengan berat badan lahir.

Menurut Sarwono (2014), paritas adalah keadaan wanita yang pernah melahirkan anak di tingkat dunia gerakan keluarga berencana telah berhasil menurunkan jumlah anak pada tiap keluarga dari 3 kelompok 2 anak, khususnya di negara maju.Paritas adalah jumlah atau banyaknya persalinan yang pernah dialami ibu baik lahir hidup maupun mati. Paritas 2 sampai 3 merupakan paritas paling aman ditinjau dari sudut kematian maternal.Ibu dengan paritas tinggi lebih dari 3 memiliki angka maternal yang tinggi karena dapat terjadi gangguan endometrium.Penyebab gangguan endometrium tersebut dikarenakan kehamilan berulang. Sedangkan pada paritas petama berisiko karena rahim baru pertama kali menerima hasil konsepsi dan keluwesan otot rahim masih terbatas untuk pertumbuhan janin.

Tingkat paritas telah menarik perhatian penelitian dalam kesehatan ibu dan anak.Dikatakannya bahwa terdapat kecenderungan kesehatan ibu yang berparitas rendah lebih baik dari pada yang berparitas tinggi, terdapat asosiasi antara tingkat paritas dan penyakitpenyakit tertentu yang berkaitan denga kehamilan.Paritas dapat dibedahkan menjadi nulipara yaitu paritas 0 , primipara yaitu 1 , multipara yaitu paritas 2-4, dan grandemultipara yaitu paritas lebih dari 4 (Sarwono, 2014).Paritas atau 
jumlah anak yang dilahirkan, dapat mempengaruhi berat badan bayi.Paritas 2 dan 3 merupakan paritas yang tidak berisiko ditinjau dari sudut kematian maternal.Sedangkan paritas 1 dan $\geq$ 4merupakan paritas yang berisiko karna selain dapat dapat mengalami BBLR, bisa juga menyebabkan kematian bayi.Sehingga Dapat disimpulkan bahwa paritas yang paling aman untuk ibu yaitu 2-3 karena baik untuk kesehatan ibu dan anak.

\section{Hubungan antara jarak kehamilan dengan Berat Badan Lahir.}

Uji korelasi pearson di peroleh nilai $p$ value $(-0,062)$ menunjukkan tidak terdapat korelasi yang bermakna antara Berat Badan Lahir dengan jarak kehamilan. Nilai korelasi pearson sebanyak 0,503 menunjukkan arah korelasi negatif berlawanan arah semakin besar nilai satu variabel, semakin kecil nilai variabel lainnya dengan kekuatan korelasi yang sangat lemah (Ho) di tolak.

Hasil penelitian ini tidak sejalan dengan hasil penelitian Purnaningsih, dkk (2015), dimana didapatkan hasil nilai $p$ value $=0,007$ atau $p<0,05$, artinya ada hubungan jarak kehamilan dengan berat badan lahir.

Menurut Sarwono (2014),jarak kehamilan adalah suatu pertimbangan untuk menentukan kehamilan yang pertama dengan kehamilan berikutnya. jarak kehamilan yang terlalu dekat menyebabkan ibu mempunyai waktu singkat untuk memulihkankondisi rahimnya agar bisa kembali ke kondisi sebelumnya. Pada ibu hamil dengan jarak yang terlalu dekat beresiko terjadi anemia dalam kehamilan.Karena cadangan zat besi ibu hamil belum pulih.Akhirnya terkuras untuk keperluan janin yang dikandungnya.menyebutkan bahwa anak- anak yang dilahirkan 3-5 tahun setelah kelahiran kakaknya, memiliki kemungkinan hidup sehat 2,5 kali lebih tinggi dari pada yang berjarak kelahiran kurang dan 2 tahun.ibu yang mempunyai anak pertama terkecil $\leq 2$ tahun namun tersebut telah mengalami kehamilan berikutnya. Jarak kehamilan $\leq 2$ tahun kondisi rahim belum kembali seperti semula selain itu ibu masih dalam proses menyusui. Komplikasi yang mungkin terjadi yaitu perdarahan setelah bayi lahir, bayi lahir namun belum cukup umur sehingga menyebabkan berat badan bayi lahir rendah $($ BBLR $)<2.500$ gram.Jarak kehamilan $\leq 2$ tahun dan $\geq 5$ tahun mempunyai. kemungkinan 1,25 kali mengalami komplikasi persalinan.Jarak kehamilan juga mempengaruhi berat badan lahir rendah atau pun berat badan lahir normal.Jarak kelahiran diukur dari kelahiran sebemlunya yang dihitung mulai tanggal awal konsepsi atau tanggal menstruasi terakhir dari kehamilan berikutnya.Jarak kehamilan kurang dari 2 tahun dapat menyebabkan tingkat kesehatan dan gizinya berada dalam kondisi buruk dan berisiko berat badan rendah. Hal ini disebabkan kadar $\mathrm{Hb}$ belum normal setelah melahirkan. Penelitian ini dapat disimpulkan bahwa yang jarak kehamilan yang paling aman untuk ibu yaitu 2-5 karena baik untuk dan anak.

\section{KESIMPULAN}

Berdasarkan hasil penelitian Hubungan dengan Berat Badan Lahir di Praktik Mandiri Bidan Mitra Mulia Banyuasin yaitu dapat disimpulkan sebagai berikut :

1. Distribusi variabel frekuensi berat badan lahir dengan persentase terbanyak pada kategori berat badan lahir normal (25004000 gram). 
2. Distribusi frekuensi umur dengan persentase terbanyak pada kategori reproduksi sehat (20-35 umur).

3. Distribusi frekuensi paritas dengan persentase terbanyak pada kategori multipara (jumlah anak 2-3 orang).

4. Distribusi frekuensi jarak kehamilan dengan persentasi terbanyak pada kategori jarak kehamilan yang aman (2-6).

5. Tidak ada hubungan antara umur ibu dengan berat badan lahir di Praktik Mandiri Bidan Mitra Mulia Banyuasin Tahun 2017-2020 dengan nilai $p$-value sebesar 0,447 lebih besar dari nilai $\alpha 0,05$.

6. Tidak ada hubungan antara paritas ibu dengan berat badan lahir di Praktik Mandiri Bidan Mitra Mulia Banyuasin Tahun 2017-2020 dengan nilai $p$-value sebesar 0,504 lebih besar dari nilai $\alpha 0,05$.

7. Tidak ada hubungan antara jarak kehamilan ibu dengan berat badan lahir di Praktik Mandiri Bidan Mitra Mulia Banyuasin Tahun 2017-2020 dengan nilai p-value sebesar 0,503 lebih besar dari nilai $\alpha 0,05$.

\section{DAFTAR PUSTAKA}

Dahlan, M. S. (2011). Statistik untuk Kedokteran dan Kesehatan. Jakarta: Salemba Medika.

Demografis dan Kesehatan Indonesia. (2017).Jakarta: Badan Pusat Statistik

Endriana Dewi Siti, N. D. (2013). Hubungan umur dan paritas ibu dengan Berat Badan Lahir. Jurnal Kebidanan, 77-83.

Hastono, S. P. (2020). Analisa Data pada Bidang Kesehatan. Depok: Rajawali Pers.

Hidayat, A. A. (2007). Metode Penelitian Kebidanan dan Teknik Analisa Data. Jakarta: Salemba Medika.
Muslihatun, I. (2010). Asuhan Neonatus Bayi dan Balita.Jakarta: EGC.

Notoatmodjo, S. (2012). Metode Penelitian Kesehatan . Jakarta: Rineka Cipta.

Ossie Happinasari, A. E. (2016). Faktorfaktor yang mempengaruhi berat badan lahir bayi. Prosiding seminar hasil penelitian bidang ilmu kesehatan dan sains teknik, 1-9.

Purnaningsih Dwi Indah, N. E. (2015). Hubungan jarak kehamilan dengan berat badan bayi baru lahir. Jurnal kebidanan , 1-8.

Profil Kesehatan. (2017). Dinkes Palembang

Profil Kesehatan. (2018). Dinkes Banyuasin

Suwarni Yunita, M. S. (2014). Hubungan antara paritas LILA, kadar HB dan umur ibu hamil dengan Berat Badan Lahir. Jurnal Publikasi Kesehatan Masyarakat Indonesia , 60-65.

Sarwono. (2014). Ilmu Kebidanan. Jakarta: Pustaka Walyani.

Walyani, E. S. (2016). Asuhan Kebidanan Persalinan dan Bayi Baru Lahir. Yogyakarta: Pustaka Baru Press.

Wahyuningrum Tria, S. N. (2015). Hubungan paritas dengan Berat Badan Lahir . Jurnal Kebidanan, 87-92.

Wigunantiningsih, A. (2017). Faktor internal yang memperngaruhi Berat Badan Lahir. Jurnal Ilmiah Maternal , 7-14 